\title{
Influence of acupuncture on the pain perception threshold of muscles submitted to repetitive strain
}

\author{
Influência da acupuntura no limiar de percepção dolorosa de musculatura submetida a esforço \\ repetitivo
}

Sandra Silvério-Lopes ${ }^{1,2}$, Maria Paula Gonçalves da Mota ${ }^{1}$

DOI 10.5935/2595-0118.20180041

\section{ABSTRACT}

BACKGROUND AND OBJECTIVES: Muscle pain is one of the causes of the leave of absence in physical activities, as well as limiting factor in sports performance. The objective of this study was to evaluate the early and late response to the pain perception threshold after acupuncture in a single application, in subjects submitted to repetitive strain.

METHODS: Clinical-experimental quantitative trial, with control group and blind, with 47 healthy women, aged between 18 and 55 years $(36.3 \pm 10.6)$, divided deterministically by sequential alternation to the groups: acupuncture (GACP n=16), Sham (Gsham $\mathrm{n}=16$ ) and control (CGRT $\mathrm{n}=15)$. The repetitive strain was performed in the Reformer equipment of the Pilates method, before and after the intervention, with $0,25 \times 40 \mathrm{~mm}$ needles. The GACP received the needling at point ST36 (Zusanli). The Gsham received superficial needling out of the acupuncture point, and the CGRT only performed the exercise. All patients had the needles for 20 minutes, except for the CGRT who remained only at rest. A digital pressure algometer was used at point BL57 (Chengshan). The algometry was conducted before the intervention and the exercise, immediately after, and after 24 hours.

RESULTS: The GACP showed a significant increase in the pain perception threshold when compared to Gsham ( $\mathrm{p}=0.021)$ and to CGRT $(\mathrm{p}<0.001)$ and after 24 hours, with CGRT ( $\mathrm{p}=0.006)$. The results were coherent with the acupuncture theoretical foundations, suggesting the release of opioid analgesics and applicability in the recovery of post-exercise sore muscles.

CONCLUSION: A single acupuncture intervention was able to increase the Pain Perception Threshold immediately and after 24 hours. Keywords: Acupuncture, Algometry, Muscle pain, Pain perception threshold.

1. Universidade Trás-os-Montes e Alto Douro, Centro de Investigaçăo em Desporto e Desenvolvimento Humano, Vila Real, Portugal.

2. Instituto Brasileiro de Terapias e Ensino, Faculdade de Tecnologia, Departamento de PósGraduação, Núcleo de Pesquisas em Acupuntura, Curitiba, PR, Brasil.

Submitted in March 14, 2018.

Accepted for publication on July 09, 2018.

Conflict of interests: none - Sponsoring sources: none.

Correspondence to:

Rua Voluntários da Pátria, 215 -2º andar - Centro

80020-000 Curitiba, PR, Brasil.

E-mail: san.silverio@yahoo.com.br

( ) Sociedade Brasileira para o Estudo da Dor

\section{RESUMO}

JUSTIFICATIVA E OBJETIVOS: A dor muscular é uma das causas de afastamento de práticas de atividades físicas e fator limitante no desempenho desportivo. O objetivo deste estudo foi avaliar a resposta imediata e tardia do limiar de percepçáo dolorosa após estímulo de acupuntura em uma única aplicação, em sujeitos submetidos a esforço repetitivo.

MÉTODOS: Ensaio clínico-experimental, quantitativo, com grupo controle e encoberto, 47 mulheres sadias, com idades entre 18 e 55 anos $(36,3 \pm 10,6)$, separadas por alocação determinista por alternância sequencial em grupos: acupuntura (GACP $\mathrm{n}=16$ ), Sham (Gsham $\mathrm{n}=16$ ) e controle (GCRT $\mathrm{n}=15)$. Realizou-se o esforço repetitivo no equipamento Reformer do método Pilates, antes e após a intervenção com agulhas $0,25 \times 40 \mathrm{~mm}$. O GACP recebeu agulhamento no ponto E36 (Zusanli). O Gsham agulhamento superficial, fora do ponto de estímulo de acupuntura e o GCRT só realizou o exercício. Todos permaneceram 20 min com agulhas e o GCRT só em repouso. Utilizou-se um algômetro de pressão digital no ponto B57 (Chengshan). A algometria foi realizada antes da intervenção e do exercício, imediatamente após, e após 24 horas.

RESULTADOS: O GACP teve aumento significativo do limiar de percepçáo dolorosa no momento imediato, quando comparado ao Gsham ( $\mathrm{p}=0,021)$ e ao GCRT ( $<0,001)$, e após 24 horas com o GCRT $(\mathrm{p}=0,006)$. Houve coerência dos resultados com as bases teóricas do estímulo da acupuntura, sugerindo liberação de opioides analgésicos e aplicabilidade em recuperação de dores musculares pós-exercícios.

CONCLUSÃO: Uma única intervenção de acupuntura foi capaz de aumentar o limiar de percepção dolorosa de imediato e após 24 horas.

Descritores: Acupuntura, Algometria, Dor muscular, Limiar de percepção dolorosa.

\section{INTRODUCTION}

Health promotion and maintenance using physical exercises is an unquestionable fact today, relying on numberless research reporting its benefits ${ }^{1-3}$. However, the behavioral factors to maintain the practice of physical activity have been of concern and object of scientific papers ${ }^{4,5}$. Studies show that approximately $50 \%$ of people who start an exercise program give up in less than six months ${ }^{6}$. There are countless reasons for quitting, and among 
them, is the post-exercise muscle pain, which is a demotivational factor to continue in the exercise program for many people ${ }^{7}$.

Muscle pain after exercises in athletes can be a limiting factor, directly impairing their physical performance ${ }^{8}$. Among the musculoskeletal pain in healthy individuals is the delayed onset muscle soreness (DOMS).

DOMS is defined as pain or discomfort experienced between 12 and 24 hours after the exercise and can have its maximum peak within 24 and 72 hours?. There are hypotheses claiming that it is a result of microlesions, where there is an initial migration of leukocytes, starting the process of tissue injury repair, while histamines, prostaglandins, kinins and $\mathrm{K}^{+}$produced by neutrophils and macrophages stimulate the free nerve endings of the muscle, causing the DOMS ${ }^{10,11}$.

Among the several studies on acupuncture (ACP), the analgesic effects are the most studied, and some of these studies look for answers to explain the mechanisms and analgesic pathways mediated by $\mathrm{ACP}^{12,13}$, while others evaluate the consensus about the therapeutical effect in vivo ${ }^{14}$. Even in specific areas like sports, the vast majority of the studies that demonstrate the ACP analgesic effects are directed to the relief of musculoskeletal pain and/ or musculoskeletal diseases ${ }^{15,16}$.

In the sports area, technology is being increasingly used in search of medals, surpassing, day after day, the limits of the human body. However, in parallel, we also see a refinement in the anti-doping assessment resources. The so-called naturist or integrative therapies are being studied as a possibility for complementary medicine to conventional interventions within sports ${ }^{17}$. However, there are few studies that investigate the acute (immediate) analgesic response of ACP interventions.

The clinical and experimental research with athletes using ACP are complex regarding the acceptance of that population since they involve variables like the fear that the technique might negatively influence the performance, and/or promote changes in physical patterns and emotional stability.

Could ACP, in a single application, have an influence on the pain perception threshold (PPT) in muscles subjected to repetitive efforts?

In this context, the objective of the present study was to evaluate the immediate and delayed PPT after the ACP stimulus in a single application in healthy, sedentary subjects, subjected to repetitive efforts.

\section{METHODS}

The study was a clinical-experimental trial with quantitative evaluation profile and control group.

The volunteers were recruited by self-selection (posters and invitations), initially constituting a group of 61 women. At the time of the study, there were a total of 47 eligible women with age between 18 and 55 years $(36.3 \pm 10.6)$.

The inclusion criteria were being female, sedentary, healthy, aged between 18 and 55 years. The exclusion criteria were being pregnant, taking analgesic, antispasmodic, anti-inflammatory, myorelaxants drugs and anesthetics within 24 hours before, during and until the last data collection. Other exclusion criteria were the performance of exercises for lower limbs (LL) strengthening in the last 5 days before the intervention, LL, lumbar and/ or sciatica pain that could interfere with the ankle plantarflexion and dorsiflexion exercise, peripheral sensitivity alterations, and smoking.

Before selecting the population of this study, a pilot test was conducted with a few male volunteers where it was concluded that males, due to their high PPT, would be inappropriate to present research. The tolerance to the pressure algometer was so high that made the evaluations operationally difficult because it was necessary to exert much force on the device and the evaluator was unable to keep the proper angle of the reading tip, which created great instabilities precluding the correct reading.

After signing the Free and Informed Consent Form (FICT), the volunteers were divided into three groups by deterministic allocation by sequential alternation, with the following composition: GACP $(n=16)$, Gsham $(n=16)$ and CGRT $(n=15)$. ACP data collection, algometry and plantarflexion and dorsiflexion exercises were conducted in the outpatient facilities of the IBRATE School in Curitiba.

First, it was conducted an evaluation of the PPT with a Wagner FDI digital algometer, of American origin, which is a dynamometer that exerts a pressure on a rubber tip when touching the skin at a $90^{\circ}$ angle. All volunteers participated in the PPT evaluation with this equipment.

The volunteers received instructions to immediately inform the surveyor when the pressure was strong enough to generate painful discomfort. This value was instantly registered on the digital algometer display as the PPT, expressed in $\mathrm{kgf} / \mathrm{cm}^{2}$. This procedure was carried out by an external surveyor, health professional, trained, who did not know which group each volunteer belonged. Three readings for each leg was collected. These data were used to calculate the percentage variation of the PPT of each volunteer between the different moments within each group and the other statistic treatments.

To take the readings, the volunteers were in the prone position on the stretcher for the analysis of a point located on the calf, in the gastrocnemius muscle. In ACP, its location corresponds to the acupoint B57 (Chengshan), according to Lian et al. ${ }^{18}$, shown in figure 1 .

The first algometric evaluation was considered the pre-treatment moment. Then, the ankle plantarflexion and dorsiflexion exercises were performed in the supine position. The Reformer equipment of the Pilates method was used with a load of $24.2 \mathrm{kgf} / \mathrm{cm}^{2}$. The exercises were standardized in the number of maximum repetitions in 1 minute, or until exhaustion within this maximum time. Exhaustion was considered the incapacity of continuing the exercise.

Right after, the intervention, the object of the present study, was performed. In the GACP, the volunteers received the needle bilaterally at the E36 acupoint (Zusanli) located 3 inches below the patella and 1 inch lateral and distal of the anterior tibial tubercle ${ }^{18}$. Disposable filiform $0.25 \times 40 \mathrm{~mm}$ Arhondin needles were used.

The depth was 1.5 inches and initially stimulated until the "deqi" sensation, which corresponds to a tingling, light shock and/or feel- 


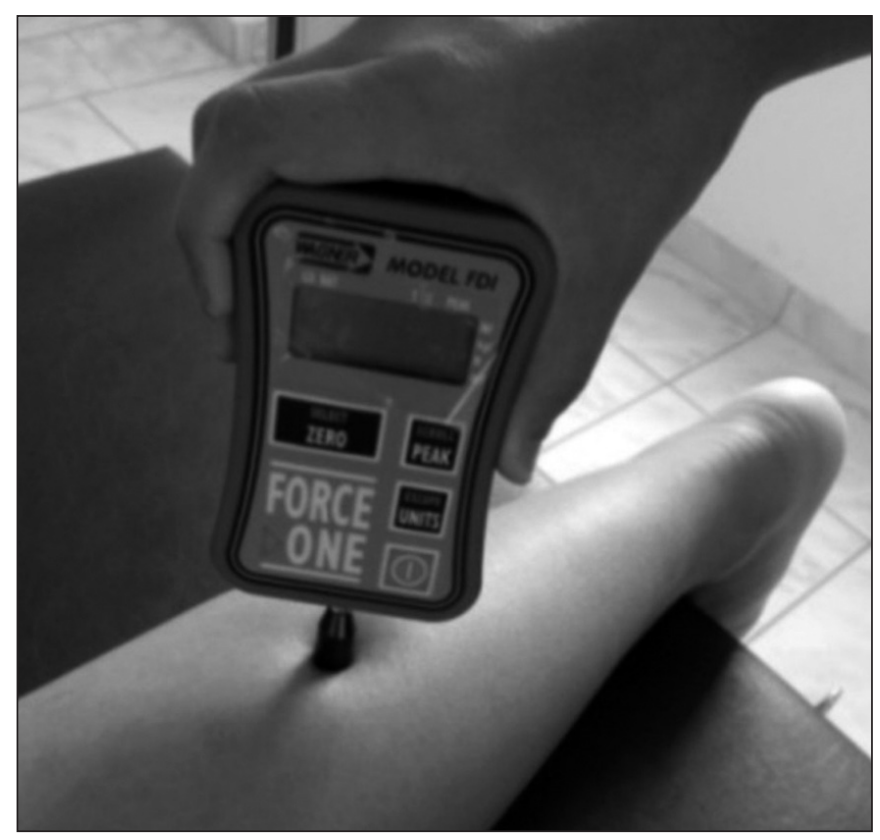

Figure 1. The pressure algometry reading at the B57 acupoint (Chengshan), in the gastrocnemius muscle

ing of heavy legs. The needle dwell time was 20 minutes for all groups. For the Gsham, the selected site was $2 \mathrm{~cm}$ medially distant from the E36 point. The CGRT received no intervention, remaining at rest on the stretcher for the same time as the others.

The volunteers did not know if they were receiving the true or sham ACP. A guest physical education teacher provided all the instructions for the exercises and the evaluations of the maximum number of repetitions in one minute at all moments. The guest teacher did not know which group each volunteer was assigned, and the surveyor was blind.

All applications were performed by an ACP expert physiotherapist. Two volunteers of the Gsham left the study. One due to non-attendance and the other because of painful high sensitivity to the algometer pressure in the immediate post reading.

The sequence of the data collection and intervention is summarized in the methodologic design of the study, as shown in figure 2 . The study was approved by the Ethics Committee of the Technology School - IBRATE, under number 225/2011.

\section{Statistical analysis}

The pressure algometry was performed on the LL with 3 PPT readings moments on each side, before, immediately after and after 24 hours.

The data obtained were subject to exploratory analysis, using the box-and-whisker and the stem and leaf diagrams to identify and purge the outliers that significantly changed the parameters of the central trend ${ }^{19}$. The assessment of the symmetry and flattening of the distribution curves was performed by the Skewness and Kurtosis values, respectively. The normality of the distributions was confirmed by the non-parametric Kolmogorov-Smirnov test, with the Lilliefors correction.

Later, using the descriptive statistics, the average and the standard deviation of the studied variables for the total sample and

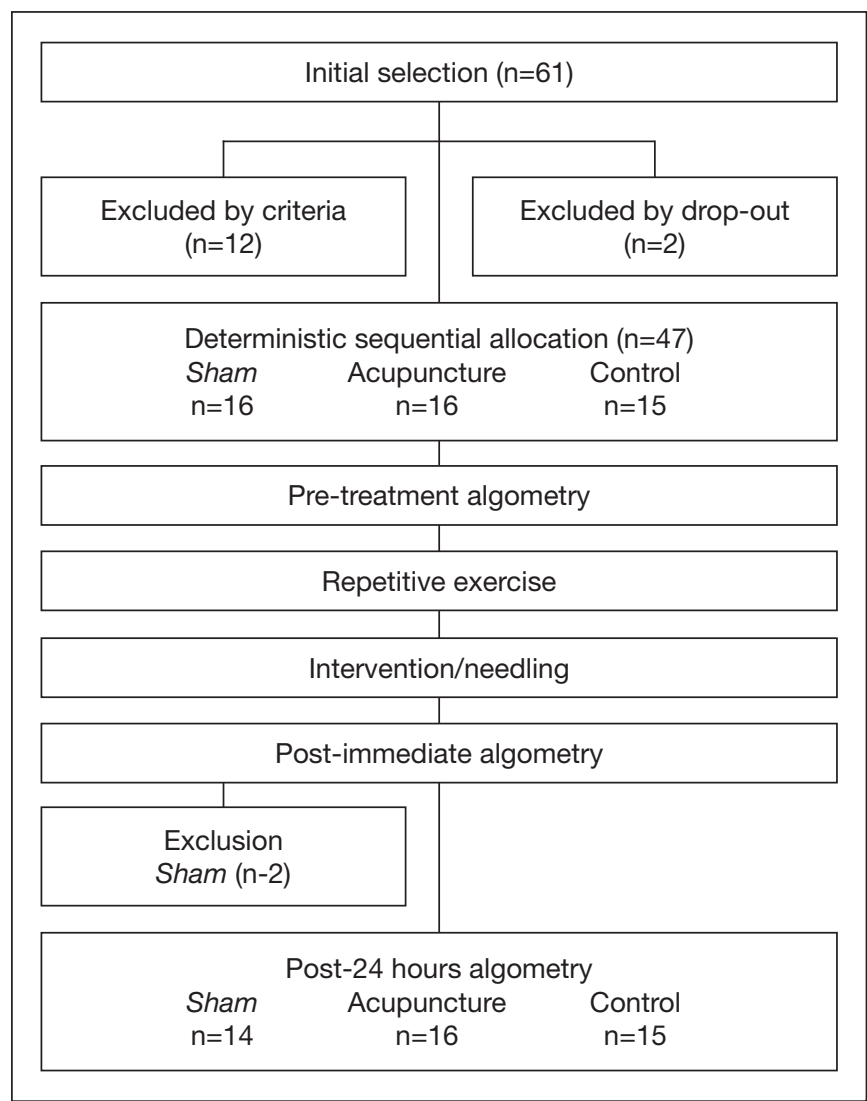

Figure 2. Methodologic design of the study regarding the moments of the exercise and intervention

by study group were calculated. The comparison between the average values obtained by each group at each moment of the evaluation was performed using the One-Way ANOVA test, with post-hoc LSD to compare two-to-two variables, with a significance level set at 5\%.

The results of the statistical analysis were expressed by the $\mathrm{p}$ values of the hypothesis tests, test power and effect size in Cohen's approach following the recommendations of the study by Lindenau and Guimarães ${ }^{20}$. The values of the One-Way ANOVA test power were obtained a posteriori considering the number of subjects in each group: in acupuncture (GACP $\mathrm{n}=16$ ), Sham (Gsham $\mathrm{n}=16$ ) and control (CGRT $\mathrm{n}=15)$ an $\mathrm{f}$ effect size of 1.29 and a level of significance of 5\%. The test power was calculated by the $G^{*}$ Power software (G*Power, Version 3.0.10, Universität Kiel, German) ${ }^{21}$, and the other analyses were performed by the SPSS statistical program, version 20.0.

\section{RESULTS}

Table 1 shows the average values $( \pm S D)$ for the age and PPT $\left(\mathrm{kgf} / \mathrm{cm}^{2}\right)$ for each group at each evaluation moment.

The comparison of the percentage variation of the PPT (kgf/ $\mathrm{cm}^{2}$ ) showed significant differences among the groups, from the pre-treatment moment to the post-immediate moment $(\mathrm{F}=8.123, \mathrm{p}=0.001$, test power: $80.2 \%)$; and from the pre-treatment moment to the post- 24 hours moment $(\mathrm{F}=4.217, \mathrm{p}=0.022$, 
Table 1. Average values ( \pm standard deviation) of the age and pain perception threshold $\left(\mathrm{kgf} / \mathrm{cm}^{2}\right)$ by algometry in the three groups at each moment

\begin{tabular}{lccccc}
\hline Groups & $\mathrm{n}$ & Average age (years) & Pre-treatment & Post-immediate & After 24 Hours \\
\hline GACP & 16 & $35.63 \pm 11.40$ & $5.91 \pm 1.74$ & $6.69 \pm 2.11$ & $6.29 \pm 1.84$ \\
Gsham & 12 & $39.83 \pm 7.79$ & $6.10 \pm 0.51$ & $6.05 \pm 0.76$ & $6.10 \pm 0.86$ \\
CGRT & 15 & $34.93 \pm 11.20$ & $7.43 \pm 1.30$ & $6.80 \pm 1.79$ & $6.54 \pm 1.91$ \\
\hline
\end{tabular}

GACP $=$ acupuncture; Gsham $=$ Sham $;$ CGRT $=$ control.

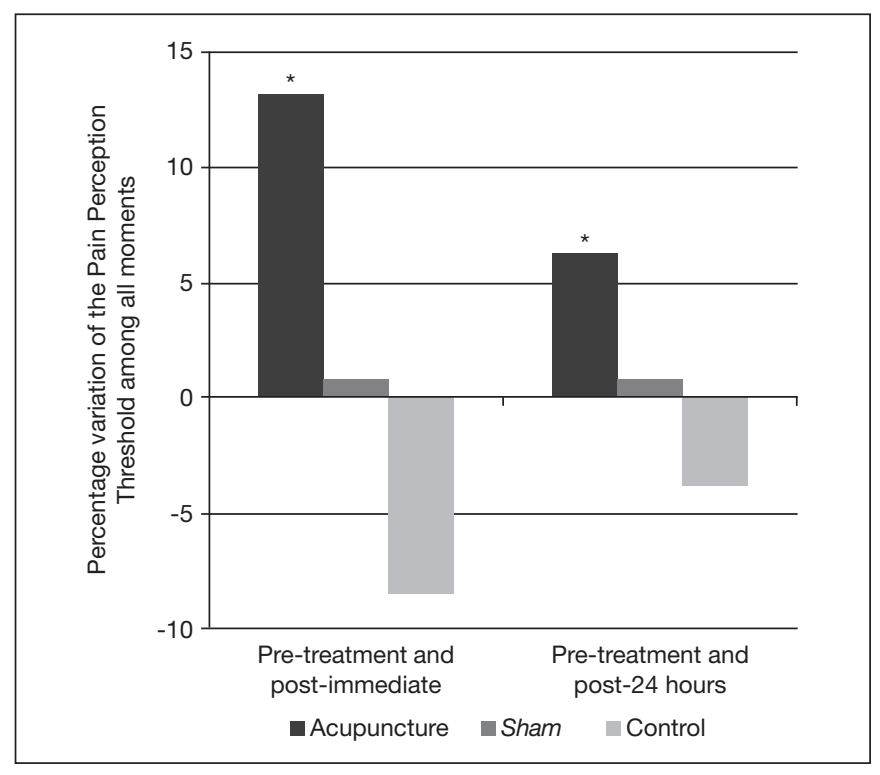

Figure 3. Percentage variation in the pain perception threshold $\left(\mathrm{kgf} / \mathrm{cm}^{2}\right)$ of each group over the three evaluation moments GACP = acupuncture; Gsham = Sham; CGRT = control. ${ }^{*} \mathrm{p}<0.05$.

test power: $75.3 \%$ ) (Figure 3). The results did not show significant differences in age among the studied groups.

When comparing the groups two-by-two regarding the percentage variation, the GACP showed a significant increase in the PPT at the immediate moment when compared with Gsham $(\mathrm{p}=0.021$; effect size: 0.87$)$ and with the CGRT ( $<<0.001$; effect size: 1.29). From the pre-treatment moment to the post-24 hours moment, the GACP showed a significant increase compared with the CGRT ( $\mathrm{p}=0.006$; effect size: 0.94). The Gsham and the CGRT did not show a significant difference between them at any moment.

\section{DISCUSSION}

The results show that one single ACP intervention at the E36 point for 20 minutes was capable to significantly increase the PPT, at the moment immediate to the application, lasting for 24 hours. These results corroborate the study by Itoh, Minakawa, and Kitakoji ${ }^{22}$ that using the pressure algometer also concluded that ACP increased the muscle fascia PTT.

$\mathrm{ACP}$ is recognized by its analgesic capacity, which releases several neuro endogenic substances capable of blocking the conduction of the painful process at its different levels ${ }^{23,24}$. Since it is uneth- ical to induce pain in healthy individuals for research purposes, the alternative, therefore, is to assess to what extent ACP can block the perception of a certain discomfort.

Pressure algometry can quantify the painful perception of the subject from the sensitization of the nociceptors ${ }^{25}$, being an indirect reference of the pain evaluation ${ }^{26}$. In the case of this study, the discomfort assessed was the mechanic pressure exerted by the tip of the algometer.

Studies by Erthal et al. ${ }^{27}$ showed the antinociceptive effects of the same ACP point studied in this research, but with the use of laser in guinea pigs and drug-induced pain. The results found in this research is in agreement with that study, although with different circumstances.

In the results, it was observed that the volunteers who did not receive needling (CGRT) presented negative variations in the average difference between the pre-treatment PPT when compared to post-treatment (immediate and post-24 hours), indicating that they were less tolerant to pressure after the exercise, which did not occur in the GACP.

The justification found for this result suggests that in addition to the requirement of the muscle involved in the proposed exercise, there is the mechanical stress on the nerve endings and nociceptors, regarding the sensitization of the pressure receptors on the surface of the tissues ${ }^{25}$. It is worth to remember that there was a load transfer from the rubber tip of the algometer on the skin, several times at the same point. Considering that these variables were the same among all the subjects, it is suggested that some antinociceptive substance, of immediate effect and/or release, has been produced in greater quantity in the GACP than in the other groups.

The selection of voluntary females proved to be adequate in this study and agrees with Chesterton et al. ${ }^{28}$, who when studying the behavior of pain perception with an algometer in different genders concluded that women have a lower PPT than men.

The site chosen to assess the PPT corresponds to the ACP B57 point. It was selected because it matches with a trigger point, making it highly sensitive to pressure ${ }^{12,29}$ and because it has a highly demanded muscle in the proposed exercise and loads. Bonfim et al. ${ }^{30}$ also used this region to assess PPT with the algometer after exercises involving the same muscle but in orthostatic position.

The results found in the present research suggest that the B57 acupoint is suitable for PPT studies with a pressure algometer, especially for exercises involving the calf muscle.

Concerning the applicability of the results found in the present study, it is possible to recommend ACP to treat the musculoskeletal pain resulting from mechanical trauma, repetitive effort, and 
muscle fatigue, where the individual needs to return to exercise in a short period of time. It is important to remember that the release of endogenous opioids leads to a consequent decrease in pain perception ${ }^{31}$, as well as other substances already studied that have probable ergogenic effects ${ }^{32}$.

This recommendation also corroborates studies reported in the literature that specifically addressed the use of ACP to improve pain symptoms in muscles submitted to physical exhaustion ${ }^{17}$. Following this line of thought, authors such as Zhu, Arsovska and Kozovska ${ }^{15}$, in a paper of clinical nature, demonstrated that ACP promoted analgesia and relaxing effects of the muscle tension in professional athletes.

In the area of acupuncture, the statistical quality is still incipient because the vast majority of studies lack statistical enhancement, which makes comparisons with other studies more difficult. The best results of this study were when the group that received acupuncture was compared with the one that received no stimulus (control), with a special and representative gain in the post-immediate evaluation, whose test power exceeded $80 \%$, the minimum desirable in the health area.

As limitations of this study is the fact that it was conducted in an exclusively feminine population due to methodological limits, as well as not being able to extend the results to the benefits of DOMS, since it hits its peak 24 to 72 hours, and the evaluation of this study was only up to 24 hours.

\section{CONCLUSION}

Based on the results, this study concluded that a single ACP intervention at the E36 point for 20 minutes was able to significantly increase the PPT at the moment right after its application, lasting after 24 hours, in healthy, sedentary women submitted to ankle plantarflexion and dorsiflexion exercises.

\section{REFERENCES}

1. Hsu CL, Best JR, Davis JC, Nagamatsu LS, Wang S, Boyd LA, et al. Aerobic exercise promotes executive functions and impacts functional neural activity among older adults with vascular cognitive impairment. Br J Sports Med. 2018;52(3):184-91.

2. McMahon EM, Corcoran P, O’Regan G, Keeley H, Cannon M, Carli V, et al. Physical activity in European adolescents and associations with anxiety, depression and well-being. Eur Child Adolesc Psychiatry. 2017;26(1):111-22.

3. Knapen J, Vancampfort D, Moriën Y, Marchal Y. Exercise therapy improves both mental and physical health in patients with major depression. Disabil Rehabil. 2015;37(16):1490-5.

4. Bishop FL, Fenge-Davies AL, Kirby S, Geraghty AW. Context effects and behaviour change techniques in randomised trials: a systematic review using the example of trials to increase adherence to physical activity in musculoskeletal pain. Psychol Health. 2015;30(1):104-21

5. Lewis BA, Napolitano MA, Buman MP, Williams DM, Nigg CR. Future directions in physical activity intervention research: expanding our focus to sedentary behaviors, technology, and dissemination. J Behav Med. 2017;40(1):112-26.
6. Nigg CR, Borrelli B, Maddock J, Dishman RK. A theory of physical activity maintenance. Appl Psychol. 2008;57(4):544-60.

7. Floegel TA, Giacobbi PR Jr, Dzierzewski JM, Aiken-Morgan AT, Roberts B, McCrae $\mathrm{CS}$, et al. Intervention markers of physical activity maintenance in older adults. Am J Health Behav. 2015;39(4):487-99.

8. Kawakita K, Okada K. Acupuncture therapy: mechanism of action, efficacy, and safety: a potential intervention for psychogenic disorders? Biopsychosoc Med. 2014;8(1):4.

9. Barros TL, Angeli G, Barros LF. Preparaçấo do atleta de esportes competitivos. Rev Soc Cardiol. 2005;15(2):114-20.

10. Foschini D, Prestes J, Charro MA. Relationship between physical exercise, muscle damage and delayed-onset muscle soreness. Rev Bras Cineantropom Desempenho Hum. 2007;9(1):101-6.

11. Byrne C, Twist C, Eston R. Neuromuscular function after exercise-induced muscle damage: theoretical and applied implications. Sports Med. 2004;34(1):49-69.

12. Qin W, Bai L, Jin L, Tian J. Findings of Acupuncture Mechanisms Using EEG and MEG. In: Tian J. (eds) Multi-Modality Neuroimaging Study on Neurobiological Mechanisms of Acupuncture. Singapore: Springer; 2018.

13. Chen X. Electric acupuncture analgesic action may differ between acupoint Zusanli and a point $0.2 \mathrm{~cm}$ beside Zusanli in rats. J Integ Med. 2014;12(3):229.

14. Vickers AJ, Vertosick EA, Lewith G, MacPherson H, Foster NE, Sherman KJ, et al Acupuncture for chronic pain: update of an individual patient data meta-analysis. J Pain. 2018;19(5):455-74

15. Zhu J, Arsovska B, Kozovska K. Acupuncture treatment for sports injury - hamstring muscles group. Inter J Clin Exper Med Sci. 2017;3(6):71-3.

16. Fong DT, Chan YY, Mok KM, Yung PS, Chan KM. Understanding acute ankle ligamentous sprain injury in sports. Sports Med Arthrosc Rehabil Ther Technol. 2009;1:14.

17. Hübscher M, Vogt L, Bernhörster M, Rosenhagen A, Banzer W. Effects of acupuncture on symptoms and muscle function in delayed-onset muscle soreness. J Altern Complement Med. 2008;14(8):1011-6.

18. Lian YL, Chen CY, Hammes M, Kol BC. Pictorial atlas of acupuncture - An ilustrated manual of acupuncture points. Potsdam, Germany: H.F. Ullmann; 2012.

19. Elliott J, Marsh C. Exploring data: an introduction to data analysis for social scientists. $2^{\text {nd }}$ ed. Polity Press; 2008

20. Lindenau JD, Guimarães LS. Calculando o tamanho de efeito no SPSS. Rev HCPA. 2012;32(3):363-81.

21. Faul F, Erdfelder E, Lang AG, Buchner A. G*Power 3: a flexible statistical power analysis program for the social, behavioral, and biomedical sciences. Behav Res Methods. 2017;39(2):175-91.

22. Itoh K, Minakawa Y, Kitakoji H. Effect of acupuncture depth on muscle pain. Chin Med. 2011;6(1):24.

23. Paschalis V, Koutedakis Y, Jamurtas AZ, Mougios V, Baltzopoulos V. Equal volumes of high and low intensity of eccentric exercise in relation to muscle damage and performance. J Strength Cond Res. 2005;19(1):184-8.

24. Hsieh YL, Hong CZ, Liu SY, Chou LW, Yang CC. Acupuncture at distant myofascial trigger spots enhances endogenous opioids in rabbits: a possible mechanism for managing myofascial pain. Acupunct Med. 2016;34(4):302-9.

25. Schenk P, Laeubli T, Klipstein A. Validity of pressure pain thresholds in female workers with and without recurrent low back pain. Eur Spine J. 2007;16(2):267-75.

26. Melia M, Schmidt M, Geissler B, König J, Krahn U, Ottersbach HJ, et al. Measuring mechanical pain: the refinement and standardization of pressure pain threshold measurements. Behav Res Methods. 2015;47(1):216-27.

27. Erthal V, Maria-Ferreira D, Werner MF, Baggio CH, Nohama P. Anti-inflammatory effect of laser acupuncture in ST36 (Zusanli) acupoint in mouse paw edema. Lasers Med Sci. 2016;31(2):315-22.

28. Chesterton LS, Barlas P, Foster NE, Baxter GD, Wright CC. Gender differences in pressure pain threshold in healthy humans. Pain. 2003;101(3):259-66.

29. Lavelle ED, Lavelle W, Smith HS. Myofascial trigger points. Anesthesiol Clin. 2007;25(4):841-51

30. Bonfim AE, De Ré D, Gaffuri J, Costal MM, Portolez JL, Bertolini GR. Uso do alongamento estático como fator interveniente na dor muscular de início tardio. Rev Bras Med Esporte. 2010;16(5):349-52.

31. Vickers AJ, Cronin AM, Maschino AC, Lewith G, MacPherson H, Foster NE, et al Acupuncture for chronic pain individual patient data meta-analysis. Arch Intern Med. 2012;172(19):1444-53.

32. Toda S. Effect of acupuncture on carnitine for skeletal muscle fatigue. Chin Med. 2012;3:9-12. 